\title{
Heinrich Leopold Wagner'in Die Kindermörderin adlı Eseri Örneğinde Çocuk Cinayeti Motifi
}

\author{
Melda Keser (iD), Tekirdă \\ https://dx.doi.org/10.37583/diyalog.802168
}

$\ddot{\partial} z$

Fırtına ve Coşku edebi akımı yazarlarından Heinrich Leopold Wagner'in Kindermörderin adlı eseri, akımın en önemli eserleri arasında gösterilmektedir. Wagner, eseri yayınlandığında, yazım stili ve konuları açıklıkla ele almış olması nedeniyle oldukça ağır eleştirilere maruz kalmıştır. Burjuva trajedisi türündeki eserinde, 18. yüzyıl toplum yaşamının en önemli konularından olan çocuk cinayeti motifini işlemiştir. Ancak, motifin karakteristik özelliği olan soylu bir erkekle saf burjuva kızı ilişsisini kurgularken, motifin ayrıntılarında değişikliğe gittiği görülmektedir. Bu bağlamda, kısaca Fırtına ve Coşku akımına ve 18. yüzyıl Alman toplumunda çocuk cinayeti olgusuna değinilecektir. Eser, dönem ve olguların arka planına dair verilen bu bilgilerden sonra, Fırtına ve Coşku akımının çocuk cinayeti motifini işleyişi ele alınacaktır. Ardından, Wagner'in, eserinde çocuk cinayeti motifini işlerken gittiği değişiklikler ve bu yolla ortaya koyduğu olgular saptanacaktır. Böylece, yürütülecek bu çalışmayla, çocuk cinayeti motifi konusunda yapılmış genel geçer tanımların dışına çıktığı ortaya konularak, Wagner'in eserine ve çocuk cinayeti motifi üzerine yapılacak araştırmalara katkı sağlanması amaçlanmıştır.

Anahtar Sözcükler: Heinrich Leopold Wagner, Çocuk cinayeti, Çocuk katili, Sturm und Drang akımı.

\begin{abstract}
Infanticide motif in Heinrich Leopold Wagner's tragedy Kindermörderin

Heinrich Leopold Wagner is one of the most important writers of the Storm and Stress period, whose drama Kindermörderin is listed among the most important works of the era. When he published his work, he was severely criticized for his style and treatment of the themes. In his bourgeois tragedy, Wagner dealt with one of the most important themes, the infanticide motif of the bourgeois life in the $18^{\text {th }}$ century. However, he structured the relationship of the noble man with the bourgeois girl in such a way that he changed some units of infanticide motif. In this perspective, this paper first briefly explains the Storm and Stress epoch and infanticide phenomena, then discusses how the Storm and Stress used this motif. With the events presented, the use of the child murder motive in Wagner's child murderer will be analyzed. The aim of this work is to contribute the important infanticide motif to the literary history works.
\end{abstract}

Keywords: Heinrich Leopold Wagner, infanticide, child murderer, Sturm und Drang Period. 


\section{EXTENDED ABSTRACT}

Heinrich Leopold Wagner is one of the most important writers of Storm and Stress, whose drama Kindermörderin is listed among the most important works of the era. When he published his work, he was severely criticized for his style and treatment of the themes. In his bourgeois tragedy, Wagner dealt with one of the most important themes, the infanticide motif of the bourgeois life in the $18^{\text {th }}$ century. However, he structured the relationship of the noble man with the bourgeois girl in such a way that he changed some units of the infanticide motif. In this perspective, this paper first briefly explains the Storm and Stress epoch and the infanticide phenomena, then, discusses how the Storm and Stress used this motif. With the events presented, the use of the child murder motif in Wagner's child murderer will be analyzed. The aim of this work is to contribute the important infanticide motif to the literary history works in the field of German language and literature.

Heinrich Leopold Wagner belonged for a long time to the forgotten ones in the history of literature, then to the ones who are reviled. Meanwhile, his bourgeois tragedy Die Kindermörderin (1776) is one of the most important dramas of Storm and Stress, along with Goethe's Götz von Berlichingen (1773), Lenzen's Der Hofmeister (1774) and Die Soldaten (1776).

Wagner was born on February 19, 1747 in Strasbourg, Alsace, as the first of seven children of the family living under precarious conditions. In 1764, he began to study theology in Halle, broke it off and in 1767 he moved back to Strasbourg, where he began to study law. During this time, he joined the table society around Johann Daniel Salzmann, got to know Goethe and Lenz and later became an employee of the weekly magazine Der Bürgerfreund, founded by Salzmann and Blessing. He produced his first translations (1770) of Montesquieu's The Temple of Gnidus as well as smaller literary works. He completed his law study after his stays in Saarbrücken (1773-774), Gießen (1774-1775) and Frankfurt (1775-1776).

In Frankfurt he continued to work as a teacher, as well as for Frankfurter gelehrten Anzeigen. His work as a writer consisted of translations, reviews, daily papers and poems. In the years 1775-1776, the most important works of Wagner are published. During this time, he also wrote his work Die Kindermörderin. When he read out his drama Kindermörderin in Strasbourg in Salzmann's circle on July 18, 1776, it was eagerly cheered. In his work, he deals with the infanticide motive, which was still one of the most important problems of society in the $18^{\text {th }}$ century.

Infanticide is also of central importance as one of the outstanding major themes of Storm and Stress. The murder of new-born children had become an explosive social problem that moved the media. It was precisely on this topic that the norm of sexual autonomy was negotiated in both its male and female variants. Infanticide is an $18^{\text {th }}$ century phenomenon that kept both the authorities and society very busy, since the number of murders was by no means reducible. The laws protected neither the new-born child nor the single mother. The young women from the middle or lower classes saw no way out but to hide her pregnancy in some way. 
For it did not come to the father if the relationship was known, but the laws determined only the punishment of the woman. Thus, the phenomenon of infanticide was thematized in literature in the $18^{\text {th }}$ century as a motive for the faithless man from the higher classes to seduce the young and naive woman from the lower classes and then, to leave her alone with the fact of social norms and the law.

However, Wagner did not structure the motif according to this pattern. The context in Kindermörderin is also the class difference and, accordingly, the social norms that constrict the woman. But he shares the role of the seducer among the characters of the mother, the father, the prostitute Marianel and the lieutenant Hasenpoth, while the father of the child, as a naive and faithful man, is on the side of the naive young woman. Thus, Wagner questions the unwritten laws, namely the norms in society, as well as the phenomena of social class, honor and morality. The law or present penalty, which can be nothing else, but the death penalty, is not mentioned in the whole work, neither by Evchen nor by any other character. 


\section{Giriş}

Heinrich Leopold Wagner, Fırtına ve Coşku döneminin önde gelen yazarlarındandır. Dönemin burjuva toplum yapısının sorunlarını irdeleyen genç yazarlardan biri olarak, kaleme aldığı eserleriyle dikkat çektiği kadar eleştirilmiştir de. 1776 yılında, dönemin en önemli toplumsal konularından olan çocuk cinayeti motifini işlediği Die Kindermörderin adlı eseri yoğun tepkiye neden olmuşsa da, günümüzde dönemin en önemli eserleri arasında anılmaktadır (Luserke 1997: 228).

Yürütülmüş çeşitli çalışmalarda, eserin tür odaklı incelendiği, özellikle sosyal drama örneği olarak ele alındığı görülmüştür. Eserde işlenen çocuk cinayeti motifi de çalışmalarda bu açıdan sadece değinilmiş öğelerden birisidir. Yürütülecek bu çalışmada ise, motifin işleniş biçimi, karakterler ve olay örgüsünün motifle nasıl bağdaştırıldığı analiz edilecektir. Böylece, eserin işlevi doğrultusunda yazarın motifi ele alış biçiminin ortaya konulması amaçlanmıştır.

Bu bağlamda, eserin dahil olduğu Fırtına ve Coşku akımının edebi özelliklerine k1saca değinildikten sonra, 18. yüzyıl Alman toplumunda, annelerin işlediği çocuk cinayetlerine dair bilgi verilecektir. Böylece "çocuk cinayeti olgusu" toplumsal yaşamda, toplum normları ve yasalar çerçevesinde anlaşılır kılınacak, ardından edebiyatta "çocuk cinayeti motifi" tanımı ve özellikleri ele alınacaktır. Heinrich Leopold Wagner hakkında kısa ve tanıtıcı biyografik bilgi verildikten sonra eserin perde perde özeti verilecek, ardından çocuk cinayeti olgusu ve çocuk cinayeti motifine ilişkin verilmiş bilgiler 1şı̆̆ında, eser üzerinde inceleme yürütülecektir.

\section{Sturm und Drang: Fırtına ve Coşku ${ }^{2}$ Akımı}

Alman Edebiyatında Fırtına ve Coşku akımı 18. yüzyılın ikinci yarısında, genç yazarların Aydınlanma akımına tepki göstermesiyle ortaya çıkmıştır. Amacı, stili ve ele aldığ́1 konularla oldukça ses getirmiştir. Rousseau'nun "insan doğas1-doğal insan" eksenindeki görüşlerinin izinde ve Shakespeare'in etkisinde gelişmiştir. Anlayışları Herder, Hamann ve Lavater'in kültür, edebiyat, deha, akıl, ilahi güç, yazarlık gibi konulardaki görüşleriyle şekillenmiştir.

Akım, Aydınlanma akımına tepki olarak ortaya çıkmış olsa da, Goethe'nin Prometheus eseriyle, Aydınlanma akımının radikal hali olarak da tanımlanmaya başlanmıştır (Luserke 2017a: 4). Aydınlanma akımı bir elit kültürü olarak görülmektedir. Eğitimli burjuva insanına yöneliktir. Soylu olmayan, fakat okur yazar olan orta sınıf insanına, varoluşunu ortaya koymayı öğretmeyi amaçlamıştır. Soylu

\footnotetext{
${ }^{2}$ Akımın Türkçeleştirilmesi konusunda basılı ve çevrim içi kaynaklarda çeşitlilik görülmektedir. Hüseyin Salihoğlu, akımı ele aldığı makalesinde "Fırtına ve Tepki" adını kullanmış, "Fırtına ve Hücum" ile "Fırtına ve Baskı" alternatiflerini de önermiştir (Salihoğlu 1988: 199). Gürsel Aytaç ise Yeni Alman Edebiyatı Tarihi başlıklı çalışmasında, dönemi "Sturm und Drang: Deha Çağı" başlığ ile adlandırmıştır (Aytaç 1992: 105). Yürütülecek olan bu çalışmada, dönem yazarlarının toplum normları konusunda farkındalık yaratma çabalarının yoğunluğu ve bunu, Wagner örneğinde de görüleceği üzere, konuları çarpıcı bir şekilde ele almalarından yola çıkılarak, "Drang" kelimesi için istenci yansıtması amacıyla "Coşku" kelimesi tercih edilmiştir.
} 
sınıfına mensup olmayan bu kişilerin "düzeltilmesi-iyileştirilmesi”, bir başka deyişle eğitilmesi amacına hizmet etmektedir. Bu nedenle, 1763-1805 y1lları arasındaki kitap basımının, 1721-1763 yılları arasındaki yayın sayısının on katı kadar artması da, toplumda okur yazar sayısının artmasına bağlanmaktadır (Luserke 2017a: 3).

Fırtına ve Coşku akımı yazarları, bireysel özgürlüğü, kimliklerin sorumluluk ve görevlerinden üstün görmektedir. $\mathrm{Bu}$ bakış açılarıyla, edebiyatta benzersiz bir "bireysellik" resmi çizmişlerdir. Benlik farkındalığı için edebiyatı en önemli araç olarak değerlendirmektedirler. Bu nedenle, akım toplumsal ve siyasi konulara hassas bir yaklaşım içindedir ve bu doğrultuda kullandığı parolalar çocuk cinayeti motifi, halk şarkıları, deha estetiği, Shakespearciliktir. Bu çerçevede yeniden ele aldığı konular ise aşk-sevgi, cinsellik, sınıf farklılıkları, edebi ve estetik değerlendirmelerdir. Akımın genç yazarları, Aydınlanma akımıyla yetişmiş kişiler olarak, Aydınlanma hareketinden öğrendikleriyle, söz konusu olguları yapıtlarında işlemişlerdir (Luserke 2017a: 2).

Eserlerin yazım stili, dil ve biçim özellikleri, estetik ve felsefesi konularında Herder'in Von deutscher Art und Kunst (1773) başlıklı yazısındaki görüşlerini dikkate almışlardır. Aydınlanmanın getirdiği 'kurallara bağlılık'tan ayrılmışlardır. Gerçek bir yaratıcılığı kısıtladığını düşündükleri için, türler arasındaki sınırları da kaldırmışlardır. Şiir, roman ve dramlar bu akımla birlikte eski kurallar dönüştürülerek yeniden şekillendirilmiştir. Ayrıca, Luserke'ye göre, bu akımın yazarları bireyin kendi kararlarını almasını sadece teşvik etmekle kalmamakta, bunu edebiyatta işledikleri konularla da göstermektedir. Böylece, eserlerinde Aydınlanma akımının amaçlarını resmettikleri gibi, işlevsiz yanlarını da okuyucuya sunmaktadırlar (Luserke 2017a: 3).

$\mathrm{Bu}$ bağlamda, Fırtına ve Coşku akımı eserlerinin karakterlerinde ikili bir başkaldırı hali dikkat çekmektedir. Dışarıdan gelen kısıtlamaya, kural koyucuya başkaldırı ihtiyacı, bunun bir yönüdür. Diğer yönü ise, bu kural koyucuya başkaldırmaya çalışırken, "aile üyelerinden birini öldürerek" bireyin kendini mahvetmesi şeklinde yaşanmaktadır. Kardeş cinayeti, baba cinayeti ve çocuk cinayeti motifleri, söz konusu başkaldırı halinin birey üzerindeki etkilerini ortaya koymak amacıyla işlendiği görülmektedir. Böylece, 18. yüzyıl burjuva toplumunun yaşamı genel hatlarıyla bu çerçevede edebi eserler yoluyla resmedilmektedir.

\section{Yüzyıl Alman Toplumunda Katil Anne ve Çocuk Cinayeti Konusu}

Toplumdaki konumu ve aile hayatı sarsıldığı için, yeni doğmuş çocuğunu öldüren anneler, 18. yüzyılda Alman toplum yaşamında ve yasalarda önemli bir olgu olarak yer almaktadır. Fırtına ve Coşku akımı yazarlarının bu olgu üzerinde durmalarının nedenine bakıldığında, toplum yaşamındaki adaletsizlikleri ortaya koymak, konuya dikkat çekmek ve dönüşüm sağlamak amacında olduklarını söylemek yanlış olmayacaktır. Ancak, yazarların bu arzusunun temelinde, evlilik dışı ilişki konusunda yasaların kadına yönelik ağır yaptırımlarının olduğu da bir gerçektir. Çünkü yasaların ön gördüğü cezalar, toplumda "zina", "fuhuş", "ahlaksızlık" olarak görülen ilişkilerin yaşanmasını 
azaltmadığı gibi, yeni doğanların öldürülmesi vakalarının artmasını da engellememiştir ${ }^{3}$.

$\mathrm{Bu}$ bağlamda, 1532 yılında çıkarılan (Carolina olarak da adlandırılan) Kral V. Karl'ın İşkence Cezaları Kanunu'na değinmek yerinde olacaktır. Çocuk cinayetleri, 16. yüzyıla kadar kanunda "akraba cinayeti” sınıfında yer alırken, V. Karl'ın çıkardığı kanunla ayrı bir suç olarak tanımlanmıştır. Kanunun 35. ve 36. maddeleri, bu tür cinayetleri işleyen annelerin yargılanması konusundadır. Yasak ilişkiden çocuk sahibi olmak ve çocuğun annesi tarafından öldürülmesi durumlarında veya bunlara ilişkin yeterli veri olması ve/veya kanı oluşması durumunda bu kanun maddeleri uygulanmaktadır. Cinayetin işlendiğine dair kanıyı oluşturacak olgu ve durumlar da kanunda listelenmiştir. Suçun işlendiğine dair şüpheler kesinleşmiş, yeterli kanı oluşmuş olmasına rağmen kadının, suçunu inkâr etmesi durumunda işkence uygulanacağ da belirtilmiştir. 131. Maddede, suçun işlenme şeklinin değerlendirilmesi ve yaptırımların saptanması belirlenirken, ardından nihai ceza olan "suda boğulma" cezas1 uygulanmaktadır (Weber 1974: 4-6; Pilz 1952: 10).

Uygulanan kanuna bakıldığında, orta veya alt sınıf kadınının bu cezalardan kaçmasının mümkün olmadığı görülmektedir. Kanunla yasaklanmış bir ilişki yaşamış olması, hamile kalması hem toplum normları hem de yasalarla çok ağır şekillerde cezalandırılırken, bu cezalara maruz kalmamak için seçtiği yol da ölümle neticelenmektedir. Çocuğunu öldürerek durumunu saklamaya çalışmak, yine de kadınlar için bu tür ilişkilerden daha olası görünmüş olmalı ki, bilhassa 18. yüzyılda bu yasalara rağmen çocuk cinayetleri artmıştır. Yasaların verdiği korkunun caydırıcı olmadığı, aksine, ilişkinin getireceği yaptırımlardan kurtulmak için yasada belirtilen diğer suçun; çocuk cinayetinin işlenmesinde artışa neden olduğu görülmüştür.

Pilz, vakalara dair bilgilere bakıldığında, bu yasalara rağmen olan artışın nedenlerini dörde ayırmaktadır. Bunlardan ilki, evlilik dışı ilişkinin yasak olması, kadının toplum içinde çok ağır şekillerde ifşa edilerek cezalandırılması, utandırılmasıdır. Kadın, yaşadığı ilişkinin bedeli olarak halka açık yerlerde çeşitli hallerde; saçlarına samandan yapılma taçlar veya ziller takılmış, elinde veya ensesine yerleştirilmiş, başının üstünden görünen bir levha ile sergilenmekte (örn.: Kilise girişinde), saçları veya kulakları kesilmekte, küçük düşürücü görevlerle cezalandırılmaktadır (Pilz 1952: 12). İkincisi; çocuğunu öldüren annelerin yoksul ailelerden gelmesidir. Bu kadınlar çoğunlukla hizmetçi veya köylü kızı veya zar zor geçinen ailelerin kızlarıdır. Böyle bir kadının hamileliğinin ortaya çıkması demek, sosyal çevresinden dışlanacağı ve çok daha korkunç bir yoksulluğa sürükleneceği anlamına gelmektedir (Pilz a.g.e.: 13). Üçüncüsü; evlilik engelidir. Teğmenlerin evlenmesinin yasak olması veya soylu bir ailenin oğlunun, kendinden aşağı bir sınıftan bir kızla evlenmesine izin verilmemesi durumudur. Dördüncüsü; doğacak olan çocuğun, evlilik dışı bir ilişskiden olması nedeniyle toplumdan dışlanacak olmasıdır. Anne, kendi durumu yüzünden çocuğunun damgalanmasını ve hayat boyu maruz kalacağı kötü muameleyi göze almamaktadır (Pilz a.g.e.: 13-14). Bu temel sebepleri, aileden ve sosyal

\footnotetext{
${ }^{3}$ Ayrıntılı bilgi için bkz.: Pilz 1952; Ulbricht 1990; Weber 1974; Wilson 2017, Luserke 1997.
} 
çevreden korkmak, adının lekelenmesi ve evlenilecek bir eş olarak görülmeyeceği korkusu gibi endişeler de çeşitlendirmektedir.

18. yüzyıl bir yanıyla, korkunç cezaların uygulandığı bir dönem olmasının yanı sıra, yasaların yeniden düzenlendiği bir dönem de olmuştur. II. Friedrich (Büyük Friedrich, hükümdarlığı 1740-1786), çocuk cinayetleri konusunda, suçu doğuran unsurları ortadan kaldırmak gerektiği görüşünde olmuştur. Bu unsurların başında, evlilik dışı ilişkilerin yasal yaptırımlarının korkunçluğunun geldiği görüşündedir. 1740 yılında, başa geçmesinin ardından, çocuk katili annelerin idamını, işkenceli ölümden doğrudan idama çevirmiştir. 1749 yılında hazırladığı tez çalışmasında, devletin bu sorunun köküne inmesinin daha iyi olacağını, böylece aşka dayalı akılsızca yaşanmış geçici ilişkilerin sebep olduğu damgalanmanın engelleneceğini belirtmiştir. 1756 yılında, "evlilik dışı doğan bebeklerin öldürülmesine, hamileliğin ve doğumun gizlenmesine karşı önlemleri” emir olarak yayınlamıştır. Emri, basit ilişkiler için o zamana dek uygulanan cezaların kaldırılmasını da içermektedir. Kararına gerekçe olarak, hamile kalmış bekar kadınların artık hamileliğinin duyulmasına dair korkularının ortadan kaldırılması gerekliliğini göstermiştir (Weber 1974: 10).

Ancak, toplumsal bir olgu olarak var olmaya devam ettiği için, evlilik dışı doğan çocukların öldürülmesi konusu tartışılmaya da devam etmiştir. Bu konudaki tartışmalar çerçevesinde, edebi metinlerde konunun ele alınması dışında, o dönem "ödül sorusu" olarak çeşitli yayınlarda topluma çağrıda bulunma yoluna da gidilmiştir. Bunlardan biri Mannheim'da, Rheinische Beiträge zur Gelehrsamkeit adlı yayın organının 1780 yılı 2. cildinde "Çocuk cinayetlerini durdurmanın en etkili yolu nedir? 100 Düka altınlık bir soru" şeklindeki çağrıdır. Çağrıya dört yüzün üzerinde çalışma ile yanıt gelmiştir (Pilz 1952: 16; Weber 1974: 16) ${ }^{4}$. Ödülü kazananlar Pfeil, Klippstein ve Kreuzfeld'dir (Weber a.g.e.: 17).

Toplumda bu denli tartışılan bir konunun, Fırtına ve Coşku akımı yazarları tarafindan edebiyatta sıklıkla kullanılmasının kaçınılmaz olduğunu söylemek yanlış olmayacaktır. Yazarlar, soylu erkek tarafından zor durumda bırakılmış genç kızın, bebeğini öldürmesi konusunu "çocuk cinayeti" motifi olarak çok sayıda eserde işlemiştir.

\section{Çocuk Cinayeti Motifi}

Çocuk cinayeti motifi, Fırtına ve Coşku akımının çok öncesinde, Antik Çağ'da da yaygın bir olgu ve motif olarak edebiyatta yer almaktadır. Antik Yunan edebiyatında ebeveynlerini öldüren çocukların veya çocuğunu öldüren ebeveynlerin hikayeleri sıklıkla karşımıza çıkmaktadır. Özellikle, annelerin çocuklarını öldürmeleri konusu, mitolojinin olağan bir parçasıdır.

Edebi aktarımların ötesinde, toplum yaşamına bakıldığında da çocukların terk edilmesi, evden gönderilmesi veya öldürülmesi, ya da mal varlığına sahip olmak için,

\footnotetext{
${ }^{4}$ Ödülü kazanan metinlerin içerikleri konusunda ayrıntılı bilgi için bkz. Luserke 1997: 221-225.
} 
ebeveynlerini öldüren evlatların kayıtlarının bulunduğu bilinmektedir. Söz konusu vakaların iki türünde de cinsiyetin önemli rol oynadığı görülmektedir. Bunlardan ilki, doğan çocuğun, kız çocuğu ise, ailenin bakımı üstlenecek maddi gücü olmadığından, terk edilmesi durumudur. Diğeri ise, erkek evladın, babanın vesayetinden kurtulmak ve özgürlüğünü elde etmek için babasını öldürmesidir (Hesse 2006: 3) ${ }^{5}$. Ancak göz ardı edilemeyecek önemli bir unsur, bu iki durum ve motifteki kişilerin, ailenin "çocuğu"Kind olarak adlandırılıyor olmasıdır. Oysa, kız çocuğu olduğu için terk edilen çocuk, henüz güç sahibi olmayan ve bedel ödeyendir. Ebeveynini öldüren çocuksa, özgürlüğünü elde etmeyi ve bu yolda "öldürme” eylemini seçmiş bilinçli bir bireydir.

Doğumundan sonra terk edilen çocukların, kız çocuğu olmak suçunu işlememiş olanları da vardır. Bunlar, Fırtına ve Coşku edebiyatında da sıklıkla konu edilen "evlilik dışı ilişkiden dünyaya gelmiş" çocuklardır. Antik Çağ'da, annesinin veya ailesinin kararına maruz kalan çocukla ortak nokta ise, toplumsal normların bedelini ödeyen konumda olmalarıdır.

Yine Antik Çağ'da aile üyeleri arasında işlenen cinayetlerde çeşitlilik görüldüğü gibi, çocuklarını öldüren ebeveyn motifinde de çeşitlilik hakimdir. Tanrıların, çocuğunu kurban etmesi motifi, mitolojide sık rastlanan çocuk ölümü motiflerindendir. Bir anlık çılgınlıkla çocuğunu öldüren anne babalar ise, yine Fırtına ve Coşku dönemi annelerinin "bir anlık aklını yitirme, çılgınlık" haliyle çocuğunu öldürmesiyle benzer görünmektedir. Ancak, mitolojideki motifte yönlendirici çılgınlık hali, Tanrıların o kişileri lanetlemesi sonucunda ortaya çıkmaktadır (Hesse 2006: 4, 127-131). Fırtına ve Coşku döneminde ise bu çılgınlık hali, kadının, çıkış yolu bulamadığı için geçirdiği buhran sonucu çıldırmasıdır.

Bunun dışında, Fırtına ve Coşku akımı edebiyatında öne çıkan çocuk cinayeti motifi bireyin varoluşu ile toplum ve yasalar arasındaki ezeli çatışmayı ortaya koyar niteliktedir. Kadın ve erkek ilişkilerinin, toplumsal normlar çerçevesinde kadına ve bu ilişkiden dünyaya gelen bebeğe bedel ödeten haliyle, mağdur kadın ekseninde şekillenmesi neticesinde ortaya çıkan bir motiftir. Frenzel'in hazırlamış olduğu Motive der Weltliteratur sözlüğünde, Kindsmord (Çocuk cinayeti motifi, Verführer und Verführte) "baştan çıkaran ve baştan çıkarılmış"6 başlığı ile ele alınmıştır. Sözlükte açıklandığı üzere bu baştan çıkarma ve çıkarılma" sözler vermek, vaatlerde bulunmak, baskı uygulamak, alkolün etkisini kullanmak, cinsel dürtülerini harekete geçirmek gibi çeşitli eylemlerle, mazbut bir genç kızı cinsel ilişkiye yönlendirilmesi, ardından kızın terk edilmesiyle, kalıcı bir ilişki yerine soruna sebep olan bir ilişki olarak kalması" şeklinde gerçekleşmektedir (Frenzel 1999: 756). Bu tanıma göre, çocuk cinayeti motifi, esasında bu motifin bir parçası, neticesidir.

\footnotetext{
${ }^{5}$ Hesse, bu konuda Platon'un yasa metinlerinin önemli bir kaynak olduğunu hatırlatmaktadır. Çocuklarını öldürmüş ebeveynler ile ebeveynini öldürmüş çocukların, yasalar tarafından hangi kriterlere göre ve ne şekillerde cezalandırdığını da ayrıntılı olarak aktarmaktadır (Hesse 2006: 3)

${ }^{6} \mathrm{Bu}$ bağlamda kavram çevirisi için "iğfal eden ve iğfal edilen", "aldatan ve aldatılan”, "kandıran ve kandırılan” vb. olasılıklar da değerlendirilebilir elbette. Bu çalışmada, söz konusu motifin içeriğindeki "baştan çıkaran bir erkeğin, baştan çıkardığı kadını zor durumda bırakması, baştan çıkarılmış olduğu için zor durumda kalmış kadın" tanımlamasını vermesi nedeniyle "Baştan çıkaran ve baştan çıkarılmış" kişi şeklindeki çeviri tercih edilmiştir.
} 
Çocuk cinayeti motifi, Themen und Motive in der Literatur adlı sözlükte ise Kindermord ("Çocuk cinayeti”) başlığı altında ele alınmıştır. Başlık altında, mitolojiden başlayarak, edebiyatta yer alan çocuk cinayeti motiflerinin çeşitliliği sunulmaktadır (Daemmrich 1995: 221-223). Fırtına ve Coşku akımında, çocuk cinayetinin eserde dönüm noktası için kullanılan bir motif olduğu aktarılmaktadır. Evlilik dışı ilişkiden dünyaya gelen çocuğun neden öldürüldüğü, bu eyleme kadını sürükleyen toplum normları ve yasalar da açıklanmaktadır. Bu akımın yazarları, çocuk cinayeti motifini, toplumsal reform için kullanmış; okuyucuda muhasebe ve sorgulama başlatmayı hedeflemiştir. Motifin kahramanları, baştan çıkaran erkek ve baştan çıkan genç kızdır. Motifin özelliği gereği erkeğin sosyal statüsü ve sınıfı kızınkinden yüksektir. Erkek, kızı terk eder. Kızın ailesi kızı kovar, sosyal çevresi yalnız bırakır. Böylece, ayıplanan ve toplumdan dışlanan bir kadın olarak çok ağır bir yalnızlık ve çaresizlik yaşamaktadır. Acı ve üzüntü nedeniyle ruh sağlığı bozulur, gerçeklik algısını sık sık yitirir, kriz anları yaşar veya agresifleşir ve sonunda çılgınlık halleri baş gösterir.

Furtına ve Coşku akımı, çocuk katili anne karakterini ve çocuk cinayeti motifini, reformist yaklaşımının bir göstergesi olarak çok sık kullanmıştır. Bu yolla eserlerde, normların çatışması durumunun öne çıkarıldığı görülmektedir. Böylece, Natüralizm akımını da kapsayacak şekilde burjuva trajedisi ve sosyal dram türlerinin bu akımda önem kazandığını söylemek yanlış olmayacaktır.

Öte yandan, eserin ilgi uyandırması için çocuk cinayeti motifinin özellikle tercih edildiği yönünde görüşler de mevcuttur. Bir çocuğun dünyaya gelişi, sevindirici bir durum olarak görüldüğünde, dram eseri ilgi çekmeyecektir. Ancak, istenmeyen veya zor durumda bırakan bir doğumsa, karakterler için problemli bir olay örgüsü oluşacaktır. Okuyucuda heyecan ve merak uyandıracak durum bu yolla yaratılmaktadır. Buna göre motif, yasak bir ilişki sonucu dünyaya gelen çocuğun, annesinin toplum normları ve yasalar nedeniyle zor duruma düşmesi sonucunda öldürülmesi, annenin, bu suçundan dolayı idamla cezalandırılması veya intihar etmesi şeklinde işlenmektedir. Motifin bu şekilde işlenmesi, ancak burjuva toplumunun ahlak normlarını temel alan bir eserde mümkündür. Hamilelik ve doğumun bu bağlamda burjuva trajedisinde sık kullanılan olgular olması olağan görülmektedir (Pütz 1970: 73-74).

\section{Heinrich Leopold Wagner}

Heinrich Leopold Wagner, sahnelendiği dönemde ses getiren Die Kindermörderin eserine rağmen, Alman Edebiyatında 'unutulmuş bir yazar' olarak tanımlanmaktadır (Werner 1977: 5; Wille 2017: 179). Yaşadığ1 dönemde eserlerine değinildiğindeyse çok eleştirilmiş, yerilmiş bir yazardır. Alımlanmasındaki bu unsurlar yine de Kindermörderin eserinin, Fırtına ve Coşku akımının ünlü eserleri Götz von Berlichingen, Der Hofmeister, Die Soldaten arasında yer almasını engellememiştir ${ }^{7}$ (Luserke 1997: 230).

\footnotetext{
7 Sonraki dönemlerde, edebiyat tarihi incelemelerinde öne çıkmasının nedenlerinden biri de, Kindermörderin eseriyle ilgili olarak Goethe tarafından intihalle suçlanmış olmasıdır. Goethe,
} 
Wagner, 19.2.1747 tarihinde, maddi olanakları kısıtlı bir ailenin yedi çocuğunun ilki olarak Strazburg'da dünyaya gelmiştir. Çocukluğu ve gençliği Strazburg'da geçmiştir. 1764 yılında Halle'de teoloji öğrenimine başlamış, 1767 yılında eğitimini yarıda bırakmış, Strazburg'a dönmüş ve hukuk öğrenimine başlamıştır. Bu süreçte Daniel Salzmann'ın topluluğuna katılmış, burada Goethe ve Lenz ile tanışmıştır.

İlerleyen süreçte, Salzmann ve Blessing'in Der Bürgersfreund adlı haftalık dergisinde çalışmaya başlamıştır. Montesquieu eserlerinin de aralarında bulunduğu çeşitli çeviriler yapmıştır. 1771 yılında, maddi zorluklar ve ilgisizliği nedeniyle hukuk öğrenimini bırakmış, 1773 yılında Saarbrücken'de meclis başkanı Hieronymus Maximilian von Günderrode'nin evinde öğretmenliğe başlamıştır (Wille 2017: 179). Beraberinde edebiyat çalışmalarını da sürdürmüştür. Öğretmenlik görevi, von Günderrode'nin yaşadığı sorunlar nedeniyle devam edememiş, Wagner 1774 yılında Gießen'e gitmiştir.

1775 baharından itibaren Frankfurt'ta yaşamaya başlamıştır. Öğretmenliğe burada devam etmiş ve Frankfurter gelehrten Anzeigen yayın evine çalışmıştır. Çalışmaları arasında çeviriler, eser tanıtımları ve eleştirileri, şiirler, günlük yazılar yer almaktadır. Frankfurt'ta, aralarında Goethe'nin de bulunduğu yazarlar topluluğu ile ilişki içindedir. Örneğin Wieland'la ve Kloppstock'la burada tanışmıştır. Goethe ile, yazarlar çevresi dışında, evlerine yaptığı ziyaretlerle de arkadaşlık etmiştir. Klinger'le dostluğunun yanı sıra, Christoph Kaufmann, Philipp Christoph Kayser, Gustav Friedrich Wilhelm Großmann ve Johann Martin Miller de Wagner'in yakın arkadaşlarıdır (Wille a.g.e.: 180).

1775-1776 yıllarında önemli eserleri yayınlamıştır. Der wohlthätige Unbekannte, eine Familien-Sczene (1775), Die Reue nach der That (1775) ve anonim bir eser olarak yayınladığı, ses getiren eseri Prometheus, Deukalion und seine Recensenten (1775) bunlardan bazılarıdır. Goethe tarafindan çevirmenliğe yönlendirilmiştir. Yaptığı çeviriler daha sonraki eserleri için ilham kaynağı da olmuştur. 1776 yılında, çevirisini yaptığı Mercier'in drama kuramından etkilendiği düşünülen Die Kindermörderin oyununu kaleme almıştır (Wille 2017: 180-181).

Wagner, yaşadığı maddi zorluklar nedeniyle ve yarım bıraktığı hukuk öğrenimini tamamlamak amacıyla 1776 yılında Strazburg'a dönmüş, eski yazarlar çevresiyle yeniden bir araya gelmiştir. Bu grup tarafından, Kindermörderin oyununun 18.7.1776 tarihinde yaptığ1 okumasında alkışlanmıştır. 28.8.1776 tarihinde hukuk alanında doktorasını tamamlamış, bir ay sonra Frankfurt'ta avukatlığa başlamıştır. Aynı yıl, 17 yaşındaki dul bir kadın olan Theodora Magdalena ile evlenmiş, eşi 1778 yılında vefat etmiştir. Eşinin ölümünden sonra bakımını kız kardeşi üstlenmiş, Wagner tüberkülozdan 4.3 .1779 'da 32 yaşında vefat etmiştir. Kısa yaşamından geriye

Wagner'in Kindermörderin eserinden çok sonra, 1808 yılında kaleme aldığı Dichtung und Wahrheit başlıklı otobiyografisinde, eserin konusunu sohbetlerinde Wagner'le kendisinin paylaştığını ve sonra eseri gördüğünde, fikrinin çalınmış olduğunu gördüğünü anlatmıştır. Wagner'den de "Strazburg'tan tanıdığım bir genç” olarak söz etmiştir (Werner 1977: 10; Pilz 1952: 18-19). 
dramaturg, öykü yazarı, çevirmen, şair ve hicivci olarak çok sayıda eser bırakmıştır (Wille 2017: 181).

\section{Die Kindermörderin Eseri}

Heinrich Leopold Wagner, Kindermörderin adlı burjuva trajedisini 1776 yılında kaleme almış ve eser aynı yıl anonim olarak sahnelenmiştir ${ }^{8}$ (Pilz 1952: 17; Riedel 2009: 6). Pest ve Preßburg'da sahnelenen, ilk halidir. Eserin işlediği konu ve işleme biçimi nedeniyle çağdaşları tarafindan sert, kaba ve uygunsuz bulunmasından dolayı, Wagner'in kendisi 1777 yılında eser üzerinde değişiklikler yapmıştır (Ulbricht 1990: 234). Bunlardan en önemlisi, eserin başlığındaki değişikliktir. Yeni başlık Evchen Humbrecht oder Ihr Mütter merkts Euch! olmuştur. Karl Lessing ise oyunu 'sahnelenebilecek' düzeye getirecek şekilde değiştirmiştir (Luserke 2017b: 336). Wagner, eseri üzerinde yapılan oynamaya Frankfurter gelehrten Anzeige adlı dergide yayınladığı yazısında “eserim hadım edilmiş!” diyerek tepki göstermiştir (Werner 1997: 6). Wagner, 1779 yılında oyuna son şeklini vermiş ve Kindermörderin adlı eserini, düşündürmek için kaleme aldığını ifade etmiştir (Luserke 2017b: 337). Amacı, toplumsal bir soruna dikkat çekmektir. Böylece eser son şeklini almış ve günümüzdeki güncel haliyle sahnelenmiştir.

Tiyatro oyunu olan eser altı perdeden oluşmaktadır. Wagner, tragedyanın üç birlik kuralını uygulamamıştır. Olay örgüsü, baş karakter olan Evchen Humbrecht'in subay von Gröningseck tarafindan tecavüze uğramasından hemen önce başlamaktadır ve Evchen'in, çocuğunu öldürmesinin ardından sonlanmaktadır. Toplamda dokuz aylık bir süreyi kapsamakta ve mekanlar genelev, Evchen'in evi (kendi odası, salon), Gröningseck'in odası, çamaşırcı kadın Marthan'ın evidir.

Gröningseck, Evchen'in ailesinin evinde kiralık odada yaşayan bekar genç bir subaydır. Evchen ve annesini, ilk kez görecekleri baloya götürmüştür, kısa bir süreliğine yemek yiyeceklerini söyleyerek, onları Gelbes Kreuz adlı geneleve götürür. Evchen'in annesi ortamın bayalığını garipser, fakat Gröningseck saf anne ve kızı, orasının yemek yenilecek düzgün bir yer olduğuna ikna eder. Gröningseck ile Evchen arasında geçen kısa konuşmalarda, Evchen'in subayı beğendiği, ondan etkilendiği görülmektedir. Evchen buna rağmen subayla arasındaki mesafeyi korumaya gayret etmektedir. Annesi ise subaya karşı aşırı derecede saygılı, buna karşın subay, anneye karşı aşırı derecede saygısız ve alaycıdır. Subay, genelevden müşterisi olduğu bir kadına para verir ve içki servisinde, annenin içkisine uyku ilacı koydurur. Anne uykuya daldığında, Evchen'i önce kur yaparak, Evchen karşı koyduğunda ise zorla yandaki odaya götürür. Perde kapandığında, Evchen tecavüze uğramış, annesi ise uyumaktadır. Gröningseck ise

\footnotetext{
${ }^{8}$ Fırtına ve Coşku akımı ile Wagner konularında birçok çalışması bulunan Matthias Luserke tarafından yürütülmüş çalışmalarda, eserin 1777 yılında kaleme alındığı ve aynı yıl yayınlandığı bilgisi de geçmektedir. Eserin farklı nüshalarının olması durumunun, ilk sahnelenme tarihlerinde baz alınan bilgi konusunda farklılıklar yaratmış olabileceği göz önünde bulundurularak, bu çalışmada erken tarihli olan sahnelenme bilgisi dikkate alınmıştır.
} 
Evchen'in tepkilerinden etkilenmiş, yaptığından pişman olmuş, Evchen'e evleneceklerine dair söz vermektedir.

İkinci perdede, ertesi gün yaşananlar verilmektedir. Evchen'in anne babası, baloya gitmek konusunda tartışmaktadır. Yakınları olan ve annenin Evchen'e ilerisi için uygun gördüğü eş adayı Magister de gelir ve tartışmaya dahil olur. Baba, baloya gitmelerini sert ifadelerle eleştirmekte, özenmelerini yermektedir. Magister, babayı ikna edecek bir orta yol bulmaya çalışır. Konuşma sırasında Gröningseck gelir ve konuşmalara katılır. Perdenin sonuna doğru Evchen de onlara katılır, fakat durgundur. Anne, Evchen'in dün geceden beri olan haline anlam veremez. Gröningseck, Magister'in konuşmalarından, ahlak ve norm konusundaki katı olmayan fakat erdemli yaklaşımından etkilenmiştir. $\mathrm{Bu}$ perdeden sonra aralarında dostluk gelişir. Annenin genelevde kaybettiği, fakat bunun farkında olmadığı ufak bir kutunun konusu açılır. Anne kutuyu bulamamaktadır. Kutuyu birinci perdede geçen genelev sahnesinde, ilacı veren Marianel bulmuş ve çalmıştır. Annenin kayıp eşyasına hayıflanması çerçevesinde, Evchen'le aralarında 'kaybedilen şeyler' konusunda konuşmalar geçer. Baba hala öfkelidir, kaba ve sert konuşmalarına devam eder. Ahlak konusunda verdiği göz dağ sonucunda Evchen'in duyduğu acı ile perde kapanır.

Üçüncü perde Gröningseck'in odasında, teğmen von Hasenpoth ile olan konuşmalarla geçer. Gröningseck, Evchen'le arasında geçenleri saklamaya çalışır. Evchen hamiledir. Kızın onurunu korumak istemektedir ve evlilik fikrinde kararlıdır. Teğmen ise ağzından laf almaya çalışırken sonunda Gröningseck'i konuşturur. Hasenpoth her şeyi öğrenir ve Gröningseck'in Evchen'le evlenmesine karşı çıkar. Subay, kızla evlenebilmek için gerekli yasal tüm adımları atacağını, görevinin buna engel olmasına izin vermeyeceğini söyler. Konuşma sırasında, Evchen'le hiç mektuplaşmamış olduklarından bahseder ve Hasenpoth, eserin motifini oluşturan olayları bu bilgi ile kurgular.

Dördüncü perde Evchen'in odasında geçmektedir. Annesi ile Gröningseck hakkında konuşmaktadırlar. Gece saat geç olmuştur ve konuşma artık gelmeyeceği çerçevesinde gelişir. Evchen üzgün ve durgundur. Melankoli hali annesinin dikkatini çeker, fakat kızının nesi olduğunu öğrenemez. Evchen'in imalı ve üstü örtülü ifadeleri konuşmayı şekillendirir. Baba da yanlarına gelir ve Evchen'in melankolik hali hakkında konuşmaya dahil olur. Anne ve babası yanından ayrılırken Evchen iç geçirerek, melankolik düşüncelerini aklından geçirir ve o esnada gizlice içeri giren Gröningseck görünür. Evchen'i teselli etmeye çalışır, fakat Evchen melankolik ve hırçındır. Durumu idare etmeleri gerektiği ve ikisinin de üzerine düşeni yapması konusunda konuşurlar. Evchen'i, sakin kalması ve sabırlı olması için ikna etmekte zorlanır.

Beşinci perde, melek Mikail anısına kutlanan bir günde, Evchen'in evinde geçmektedir. Evin yardımcısı Lissel ile Evchen, sabahın çok erken saatinde, Evchen'in odasında konuşmaktadır. Gröningseck imzasıyla kendisine gelmiş ve evlenmeyeceklerini bildiren mektubu almıştır. Evchen, Lissel'in mantosunu ister ve kendininkiyle değiştirir. Lissel'e hiçbir açıklama yapmadan ve anne babasına görünmeden evden kaçar. Hemen ardından Magister gelir evlerine ve Evchen'in 
babasıyla konuşmak ister. Magister, kilisedeki bir vaaz sırasında, Evchen'in kadınların onuru, evlilik dışı ilişki ve hamilelik konularının geçtiği esnada bayılmasından, hamile olduğunu anlamıştır. Ayrıca, elinde Evchen'in babasına Gröningseck imzasıyla yazılmış bir mektup vardır. Uzun tartışmalardan sonra, Evchen'in durumu anlaş1lır, Magister mektubu babaya verir. Mektup Evchen'i ve aileyi aşağılayan tonda yazılmıştır. Anne sinir krizi geçirir. Olayların ortasına, annenin kayıp kutusunu getiren karakol görevlisi genç gelir. Baba, daha önce şahit olduğu bir davranışını ahlaksız bulduğu için genci döver ve kovar. Ardından genç, amiriyle birlikte geri gelir. Kutunun hikayesi ve anne kızın o gece geneleve gitmiş oldukları ortaya çıkar.

Altıncı perdede, Evchen çamaşırcı kadın Marthan'ın evindedir. Çocuk doğmuş ve açlıktan sürekli ağlamaktadır. Evchen'in de Marthan'ın da hiç parası yoktur. Çocuğa bir lokma yiyecek bulamadıklarını ve durumu konuşurlar. Marthan, çevrelerinde yakın zamanda yaşanmış bir aile trajedisini anlatır. Kızın annesinin kahırdan öldüğünü söyler. Anlattığı olay, Evchen'in yaşadığı olaydır. Evchen dayanamaz ve Marthan'a her şeyi anlatır. Evchen'in babası, kızını bulana 100 sikke vereceğini duyurmuştur. Evchen, Marthan'ı babasına gönderir. Marthan gittikten sonra, bebeğin ağlamalarının arttığı bir anda Evchen melankoliyle kendini kaybeder ve çocuğun şakağına batırdığı iğneyle cinayeti işler. Marthan, babası ve polis aynı anda gelirler, hemen ardından da Gröningseck gelir. Polisler Evchen'i götürmek isterken, Gröningseck engel olmaya çalışır, Fransa kralına gidip, Evchen'i affetmesini isteyeceğini, Evchen'in suçsuz olduğunu söyler. Evchen'in babasının, Gröningseck'in götürdüğü baloya lanet etmesiyle perde kapanır.

\section{Die Kindermörderin Eserinde Çocuk Cinayeti Motifinin İşlenişi}

Matthias Luserke, Fırtına ve Coşku akımı yazarlarının 1770'li yıllarda kaleme aldığı çocuk cinayeti motifli eserlerini sıralamakta ve aralarından edebiyat tarihi incelemeleri açısından en etkilisinin Wagner'in Kindermörderin adlı eseri olduğunu ifade etmektedir (Luserke 1997: 228). İlk sahnelendiğinde, estetik özelliklerinin zayıf olduğu, olay örgüsü kadar, karakterlerin konuşmalarının, stillerinin ortaya koyuluş şekli de eleştirilmiştir. Oysa Wagner, eserini dönemine göre modern bir stilde ve natüralist özelliklerde kaleme almıştır (Pilz 1952: 10). Wagner, natüralist ve ekspresyonist yazarlar tarafından öncü olarak da tanımlamıştır (Werner 1977: 11).

Wagner'in seçtiği kahramanların konuşma stili doğal haliyle yansıtılmıştır. Böylece, toplumun farklı kesimlerinden oluşan dünya, eserde gerçeklik çerçevesinde verilmiştir. Gröningseck konuşmalarına sıklıkla Fransızca ifadeler serpiştirmekte ve üst perdeden konuşmaktadır. Evchen ile duygusal yakınlık kurduğu, onunla iletişiminde ahlaklı ve erdemli davrandığı sahnelere dek bu tutumu görülmektedir. O zamana kadar ise konuşma biçimi, egoist tutumuna uygun şekilde şımarık ve küstahtır. İlk perdede Evchen'e karşı şımarık davranmasının yanı sıra, Evchen'in annesine ve hayat kadını Marianel'e karşı son derece kaba ve saygısızdır. Marienel'i alenen, yüzüne karşı fahişe diyerek aşağılamakta, Evchen'in annesini konuşurken ciddiye almamakta ve basit bir kadın muamelesi yapmakta, kalçasından kucaklamakta, bacaklarının arasına 
sıkıştırmaktadır. Evchen'le birlikte olduktan sonra, gördüğü tepkiyle bir şok yaşamakta ve Evchen'e karşı davranışları değişmektedir. Aileye karşı davranışlarında ve konuşma biçimindeki şımarıklık ve özgüven ise, Magister'in görüşlerinden etkilenmesiyle tamamen ortadan kalkmaktadır.

Anne, Gröningseck'in saygısız ve şımarık davranışlarına, konuşmalarına hiçbir tepki vermemektedir. Buna, genelevdeki odada bulunan yatağın hiç de kötü olmadığını ifade ederken "yarı yatak, yarı kanepe, [...] düğün gecenizde bile bundan iyisinde yatmamışsınızdır değil mi Bayan Humbrecht? - Gerçi sadece saman yığını - ama iyi doldurulmuş! Elastik!” şeklindeki konuşması (Wagner 2014: 7) önemli bir örnektir. Hem toplumsal normlara göre kutsal olan evliliği hem de annenin yaşam standardını, sınıfını aşağılamaktadır. Diğer önemli bir örnek ise, Gröningseck odada lambayı yere düşürdüğünde, annenin telaşlanarak “Ay lamba! Teğmen Bey lamba!” demesi, Gröningseck'in ise onu ciddiye almak bir yana, ağzını yansılayarak alay etmesidir (a.g.e.: 6). Annenin, Gröningseck'in unvanını karıştırması, olduğundan yüksek bir rütbeyi kullanması birinci perdede birkaç kez görülür ve aralarındaki konuşmada da konu edilir (a.g.e.: 5).

Evchen 17 yaşındadır ve ailesine göre evlenmek için de henüz küçüktür. Evin masum, saf genç kızı ve onurudur. Babası tutucudur, eski kafalı olarak resmedilmektedir. Balo eğlencesini ilk kez görecek olan anne ve kızına, en başından itibaren karşı çıkmakta, onların hevesini yermektedir. Bu konudaki konuşmaların tamamı, babanın öfke patlamaları etrafında şekillenmektedir. Son sahnede de olan her şey için balo sevdasını göstermektedir. "Ne kadar gerekliyse verirdim, yeter ki o balo yaşattığ1 her şeyle birlikte cehennemin dibine gitseydi!" (a.g.e.: 85) diyerek Gröningseck'e haykırmasıyla oyun biter.

Hayat kadını Marianel, Gröningseck'i sevmemekte, elinde olsa ondan intikam almak istemektedir. Fakat, kendisini aşağılayan ve bir genç kızı tuzağa düşürecek olan adama para için yardım eder, suç işler (a.g.e.: 8-9,16-17).

Teğmen von Hasenpoth, Evchen'in baştan çıkarılmasında değil, ortada bırakıldığını sanması ve aklını kaybetmesinde yönlendirici roldedir. Gröningseck'in yazısını tanımadığını bildiği Evchen'e yazdığı mektupla kızı yanıltmıştır. Ayrıca mektupta, Evchen'e Hasenpoth'u aday olarak önermiştir (a.g.e.: 56). Evchen'i sosyal sınıfı nedeniyle evlilik için uygun görmediğini, Gröningseck'le yaşadığı tartışmada açıklıkla ifade etmekte (a.g.e.: 33-35) ve tüm oyunu bu evliliğin gerçekleşmemesi için oynamaktadır. Ancak, hepsinin içinde kendisinin de faydalanabileceği bir olasılık da yaratmaya çalışmıştır. Baştan çıkaran (Verführer) karakterini, ana karakterin rolünden farklı bir yolla gerçekleştirmeye çalışmaktadır.

$\mathrm{Bu}$ bağlamda, Evchen'in girmek istemediği ve hayatını alt üst eden cinsel ilişkiyi sağlayan şartlarda rol alan diğer kişiler de Hasenpoth gibi, baştan çıkaranVerführer rolüne ortak olanlardır. Anne, cahil görünümü altında, 17 yaşındaki kızı kadar heveslidir farklı dünyaları görmeye. Baloya gitmekte kızı kadar 1srarcıdır. Bulundukları ortamın genelev olduğunu anlamasa bile, Gröningseck'in kendisine ve kızına karş1 şımarık ve sırnaşık davranışlarına hiçbir tepki göstermez, baloya dönmek üzere orada 
kalmaya, içki içmeye devam eder. Genelevde çalışan ve Gröningseck'in müşterisi olduğu Marianel, kendisini görevlendirirken bile hakaretler eden Gröningseck'in talimatını harfi harfine yerine getirir. Subaydan, dilediği intikamı alma şansı olmasa da, uyku ilacını anneyi uyutacak kadar içkiye eklememeyi düşünmez. Evchen'in babası ise ahlaki normlar konusunda uyguladığı baskıyla, kızını ve karısını burjuva dışı yaşamdan izole etmiş, cahil bırakmıştır. Tüm ahlaki değerlerine rağmen, evinin odasını genç ve bekar bir subaya vererek, kızıyla aynı çatı altında yaşanmasına "maddi sebeplerden" dolayı izin verdiği anlaşılmaktadır. Bu bağlamda, eserde çocuk cinayeti motifini ortaya koyan salt kadın-erkek ilişkisinin Evchen ve soylu bir subay arasında cereyan etmediği, subayın tecavüzünden dolayı yaşanmadığı, baştan çıkaran-Verführer rolünün bu beş karaktere bölüştürüldüğünü söylemek yanlış olmayacaktır.

Fırtına ve Coşku akımı eserlerinde işlenen çocuk cinayeti motifindeki "evlilik dışı ilişkiden dünyaya gelen çocuğun" toplumsal normlar nedeniyle anne tarafından öldürülmesi bu eserde de temel motif olarak görünmektedir. Ancak, eserde yasaların bu hamilelik için gerektirdiği cezaların konusu hiç geçmemektedir. Onun yerine "baba figürü" ve "aile şerefi”, "kadının onuru” olguları yönlendiricidir. Evchen'in melankolisinin nedeni bu olguların yüklediği sorumluluk duygusudur. Üzgün ruh haline dair anneyle her konuşmasında, hayıflanan hali, onur ve şeref konusunda ödeyeceği bedelden, kendini kirletilmiş görmesindendir. Olay yaşandığında, annesi hala uyuyorken "uyu anne uyu, sonsuza kadar uyu! Kızın fahişe yapıldı!" (a.g.e.: 16) diye haykırmış, sonrasındaki tüm anne-kız bağı, baba-kız sevgisi, aile sevgisi konularındaki konuşmalarında üstü örtülü ve imalı ifadelerinde bu bakış açısını vurgulamıştır.

Magister'in mektupla olayları açıklığa kavuşturduğu sahnede de kanunların, yasal yaptırımların konusu hiç geçmemektedir. Annenin tepkisi "Evchen'imin onuruna laf söyleyen, benim can damarıma basar!" (a.g.e.: 60), babanın tepkisi ise "Bir öküz gibi alnımdan vuruldum! Her yere haber salın, nerede olduğuna (Evchen'in) bakın!" şeklindedir. Evchen ise ailesinden kaçmıştır. Gröningseck'in, kendisiyle evlenmek istemediğini düşündüğü için, kendine kalacak başka bir yer bulmuştur. İntihar etmemiş, yasalardan korkarak hareket etmemiş, çocuğunu doğar doğmaz öldürmemiştir.

Evchen, çocuğuna bakmaya çalışmakta, açlıkla mücadele etmektedir. O durumdayken, annesinin kendisi yüzünden öldüğünü öğrendiğinde yaşadığı acıyla aklı bulanır. Önce ninni söylemektedir çocuğa, "bizim ninnimizi mi söylüyorsun" der ve bebeği kucağına alıp severken ekler “söyle Gröningseck'cik söyle! Öyle ya, babanın adı Gröningseck'ti! Kötü bir baba, sana ve bana hiçbir şey olmak istemeyen bir baba!" (a.g.e.: 79). "Ben fahişeyim, anne katiliyim, sen henüz hiçbir şey değilsin, küçücük bir piçsin, başka hiçbir şey değil! Hiçbir zaman benim olduğum şey olmayacaksın, benim katlandıklarıma katlanmak zorunda kalmayacaksın" dedikten sonra, çocuğunu öldürmüştür. Yasalar ve gerektirdiği ceza, ilk ve tek kez bu sahneden sonra, Evchen'i polisler almaya geldiğinde geçmektedir. Gröningseck, Evchen'i kurtarmak istemektedir. Böylece, bu eserde "yasaların", "yasalardan duyulan korkunun" değil, aile ve sosyal çevreden duyulan korkunun, toplum normlarının, burjuva sınıfının ahlak anlayışının yönlendirici olduğunu söylemek yanlış olmayacaktır. 
Ancak bu noktada, çocuk cinayetlerinin nedenlerinden biri olan "evlilik engeli"nin temel sebep olduğu da görülmektedir. Subay Gröningseck mesleği ve konumu nedeniyle evlilik için zamana ihtiyacı olan, bunun için çabalayan, hastalandığı için süreci mecburen uzatmak zorunda kalan bir erkektir. Evchen'le ilişkisi normal düzeyde başlamamış, subayın cinsel ilişki için başlattığı bir bağdır, fakat duyguları değişmiştir. Evchen'le gerçekten evlenmek istemektedir.

Gröningseck, evlilik engelini ortadan kaldırmaya çalışırken, Hasenpoth'un oynadığı oyunla, hali hazırda güven sorunu yaşayan ve rezil olmaktan korkan Evchen'in melankolisi ve güvensizliği olayı tırmandırmıştır. Olayların sonucunda bebek ve annesi bedel ödemiştir.

$\mathrm{Bu}$ bağlamda, baştan çıkaran (Verführer) erkek rolünün bu eserde temelinden değişikliğe uğradığını söylemek yanlış olmayacaktır. Evchen'in Gröningseck'e zaafı vardır, Gröningseck bu zaaftan faydalanmıştır. Fakat hemen sonrasında bu rolden çıkmış, Evchen'e ve çocuğuna sahip çıkmak için uğraşan bir babaya dönüşmüştür. Kızı tuzağa düşüren kişi rolü, başka bir soylu askere; Hasenpoth'a geçmiştir. Hasenpoth, kızın hamile kalmasında, ilişkinin başlamasında hiç rol sahibi değilken, çocuk cinayetine neden olan kişi konumuna gelmiştir.

Trajediyle sonlanmayacak ve çocuk cinayeti motifini gerektirmeyecek bir kadın erkek ilişkisi, sınıf farkı ve soylu sınıfı normları nedeniyle çıkmaza girmiştir. Böylece Fırtına ve Coşku edebiyatındaki, izleyiciye muhasebe yaptırılması amacının ortaya konduğunu söylemek mümkündür.

Eserin, insanı salt doğası ekseninde ele almayı amaçlayan Fırtına ve Coşku akımı eseri olarak, sınıf farklılıkları ve toplumsal normların verdiği zararı, çocuk cinayeti motifini kullanarak dikkat çekecek şekilde sunduğunu söylemek yanlış olmayacaktır. Aynı hikâye, Gröningseck'in vaktinde yetişmesiyle, çocuk ölmeden, anne ve çocuk, bedeli hayatıyla ödemeden sonlanacaktı. Tehlike son anda atlatılmış, toplumda sıklıkla yaşanan veya yaşanması çok muhtemel bir trajedi izleyiciye bu denli çarpıcılıkta sunulamayacaktı.

\section{Sonuç}

Heinrich Leopold Wagner'in çocuk cinayeti motifini işlediği bu eseri incelendiğinde, motifin sadece temel bir motif olarak kullanıldığı görülmektedir. 18. yüzyıl burjuva toplumunda genç kızların sınıf, ahlak, erdem, onur gibi olgular nedeniyle yaşadığı yaşamsal sorunları oluşturan çeşitli motiflerin işlenmesi için kullanılmıştır.

Çocuk cinayeti motifi için yapılan tanımlarda genel geçer kural halini alan "baştan çıkaran ve ortada bırakan soylu erkek" ile "baştan çıkarılan alt sınıf kadını" örgüsü bu eserde önemli değişiklikler uygulanarak işlenmiştir. Genç kızı zor duruma

düşüren erkek rolü, Gröningseck’ten Hasenpoth'a geçmiştir. Öte yandan, Gröningseck yaşadığı duygusal dönüşümle o rolden tamamen çıkarken, anne, baba, hayat kadını Marianel ve Hasenpoth eserin tamamında bu rolü bölüşmektedir. 
Genç kızın saf ve masum hali ise, Evchen'in melankolisiyle verilmektedir. Ancak bu bağlamda, bu masumiyetin Evchen'i aklayan değil, bilakis zora sokan, hayatının mahvolmasına hizmet eden bir faktör olduğu açıktır. Saflığı, ailesinin şeref ve onurunu düşünerek yaşadığı melankolisi trajediyi tamamlayan öğe olarak görünmektedir. Melankolisinin yükseldiği anda çocuğunu öldürmüştür. Her bir karakterin eylemi, burjuva yaşamına dair çok çeşitli konuları ve motifleri sunmaktadır. Bunları ayrı bir çalışmada incelemek, motif çalışmalarına önemli bir katkı sağlayacaktır.

Eserde mağdur kadının durumunun, sadece toplumsal ahlak değerleri üzerinden işlendiği görülmektedir. Yasa ve yaptırımların konusu hiç geçmemektedir. Evchen'in tüm korkusu, ahlaksız olarak damgalanacak ve ortada kalacak olmasıdır. Evlilik dışı ilişki bağlamında yasa ve cezalar sadece son sahnede, cinayet sebebiyle Marthan'ın "polise haber vermesi gerektiğini” söylediği ve polislerin Evchen'i götürdügü sahnede "Gröningseck'in, Evchen'in suçsuz olduğunu, Kral'a gidip cezayı kaldırmasını isteyeceğini söylediği”" anlardır.

Fırtına ve Coşku akımının edebi konularından olan "bireyin iki yönlü başkaldırı ihtiyacı ile aileden birini öldürmesi” durumunun, Evchen'in üzüntüden ölen annesi için duyduğu aciyla çocuğunu öldürmesi üzerinden işlendiği görülmektedir. Annesinin ölümüne sebep olduğunu duyduğu ana kadar çocuğuna sahip çıkmakta ve hayatta kalmaya çalışmaktadır. Oysa bireyin özgürlüğü, seçim hakkı temel konu iken, Evchen kendine bu alanı sağlayamadığ 1 gibi, aileden bir kişinin ölümüne istemeyerek sebep olmuştur. Tekrar seçim yapıp her şeyden kurtulmak içinse çocuğunu öldürmüştür. Ardından intihar etmeyi düşünüp düşünmediği, diğer karakterlerin sahnede belirmesiyle üstü kapalı kalmıştır. Ancak, Evchen'in durumundaki bir kadının ölüm cezası almadan kurtulamayacağı, dönemin yasalarında açıkça belirtilmiştir. Dolayısıyla Evchen'in, ölümü bir çıkış yolu olarak seçtiği anlaşılmaktadır. Ancak seçimini, melankoli ve bir anlık çılgınlıkla yapmış, kurtulmak için öncelikle çocuğunu öldürmüştür.

Eserin motif kurgusu ve olay örgüsünde, toplumun ilişkiye ve birey hayatına dahlinin incelikle ve büyük bir ustalıkla işlendiği görülürken, Wagner'in "hadım edildi" dediği ve kendisinin de değiştirerek bir dönem yayınladığı nüshalarını incelemek gerekliliği de ortaya çıkmaktadır. Ayrı bir çalışma konusu olarak ele alınması, aynı dönemin iki yazarının motifi aynı eserde üç farklı şekilde işleme şeklinin görülmesi bakımından katkı sağlayacaktır. Nitekim Wagner, kendi yaptığı değişiklikle, eserin sonunu değiştirmiş, fakat daha sonra eseri eski haline çevirmiştir. Karşılaştırmalı bir çalışmayı gerektireceğinden, bu çalışmanın sınırları nedeniyle konu ele alınmamıştır.

\section{Kaynakça}

Aytaç, Gürsel (1992): Yeni Alman Edebiyatı Tarihi. Ankara: Gündoğan Yayınları.

Daemmrich, Horst S (1995): Themen und Motive in der Literatur: ein Handbuch. Hg. Horst S. u Ingrid Daemmrich. 2. überab. und. erw. Aufl. - Tübingen; Basel: Francke. 
Hesse, Katrin (2006): Kindsmord und Wahnsinn. Untersuchungen zur Überlieferung mordender Eltern in der Antike. Inauguraldissertation zur Erlangung des Doktorgrades, vorgelegt der Philosophischen Fakultät der Ruprecht-Karls-Universität zu Heidelberg.

Frenzel, Elisabeth (1999): Motive der Weltiteratur. Ein Lexikon dichtungsschnittlicher Langsschnitte. 5. überab. und ergänzte Auflage. Stuttgart: Kröner.

Luserke, Matthias (1997): Sturm und Drang: Autoren - Texte - Themen. Stuttgart: Reclam.

Luserke-Jaqui, Matthias (2017a): Sturm und Drang als Programm. Handbuch Sturm und Drang. Hg. Matthias Luserke-Jaqui u.a., Berlin u.a.: De Gruyter. 1-7

Luserke-Jaqui, Matthias (2017b): Die Kindermörderin (Wagner). Handbuch Sturm und Drang. Hg. Matthias Luserke-Jaqui u.a., Berlin u.a.: De Gruyter.328-337.

Pilz, Georg (1952): Deutsche Kindesmordtragödien: Wagner, Goethe, Hebbel, Hauptmann. 1. Aufl.München: Oldenburg.

Pütz, Peter (1970): Die Zeit im Drama. Zur Technik dramatische Spannung. Göttingen: Vandenhoeck \& Ruprecht.

Riedel, Norman (2009): Die Gretchentragödie und Wagners Kindermörderin. Ein vergleich. Noderstedt: Grin.

Salihoğlu, Hüseyin (1988): Alman Edebiyatında Firtına ve Tepki. Hacettepe Üniversitesi Eğitim Fakültesi Dergisi, Sayı 3. 199-208.

Stauf, Renate (1997): Sturm und Drang, Geistiger Aufbruch 1770-1790 im Spiegel der Literatur. Hg. Plachta, Bodo u.a., Tübingen: Max Niemeyer Verlag.199-214.

Ulbricht, Otto (1990): Kindsmord und Aufklärung in Deutschland. Ancien Régime, Aufklärung und Revolution. Hg. Reichardt, Rolf u.a., Band 18. München: R. Oldenburg Verlag.

Wagner, Heinrich Leopold (2014): Die Kindermörderin. Bibliographisch ergänzte Ausgabe. Stuttgart: Reclam.

Weber, Beat (1974): Kindsmörderin im deutschen Schrifttum von 1770-1795. Bonn: Bouvier Verlag.

Werner, Johannes (1977): Gesellschaft in literarischer Form: H.L. Wagners 'Kindermörderin' als Epochen und Methodenparadigma. 1. Aufl. Stuttgart: Klett.

Wille, Lisa (2017): Wagner, Heinrich Leopold. Handbuch Sturm und Drang. Hg. Matthias Luserke-Jaqui u.a., Berlin u.a.: De Gruyter.179-185.

Wilson, W. Daniel (2017): Kindsmord. Handbuch Sturm und Drang. Hg. Matthias Luserke-Jaqui u.a., Berlin u.a.: De Gruyter. 68-73. 